\title{
A Survey of Urban Tree Management in New Zealand
}

\author{
Matthew Stobbart and Mark Johnston
}

\begin{abstract}
Local authorities in New Zealand are responsible for managing many of the publicly owned trees in their district and have a statutory duty to act as an environmental guardian for trees that have a significant amenity or cultural value. No previous research had been completed to investigate, on a national scale, the efficiency and effectiveness of local authority tree management. A survey questionnaire was designed to assess the extent that tree management is planned, systematic, and integrated and to identify the key challenges and limitations local authorities face in managing the urban forest.

A survey questionnaire was sent to each of New Zealand's 73 local authorities. Thirty questionnaires were returned giving a response rate of $41 \%$. Many local authority tree management programs were found to be operating under difficult conditions and often within severe financial constraints. A lack of basic information about the urban forest was making it difficult for many local authorities to develop meaningful strategies and budgets and was reflected in low levels of planned maintenance. Resource constraints, conflicting priorities, and a lack of public and political support were all highlighted as being significant threats to many tree programs.

Key Words. Local Authority; New Zealand; Surveys; Tree Management.
\end{abstract}

Managing the trees in New Zealand's towns and cities is essentially a local government function with local authorities (LAs) managing many of the publicly owned trees in their district. The Resource Management Act (Ministry for the Environment 1991) creates a statutory duty for LAs to act as environmental guardians for many of the natural resources in their district. A key requirement of the Resource Management Act is the preparation of a district-wide plan setting out how each LA intends to fulfill its statutory obligations. This process includes an implied responsibility for LAs to identify and protect trees in their districts that have significant amenity, cultural, or heritage values.

The relevance of well managed tree populations in New Zealand's towns and cities is illustrated by the extent to which the country has become urbanized. Despite having a land mass similar in size to the United Kingdom (UK) and a resident population of only 4.3 million people (Statistics New Zealand 2010), 86\% of New Zealand's population lives in urban areas (Population Reference Bureau 2010). It is estimated that $72 \%$ of New Zealand's population lives in the 16 main urban areas with $54 \%$ living in one of the four main cities: Auckland, Hamilton, Wellington, and Christchurch (Statistics New Zealand 2010). Away from the main urban centers, LA districts are predominantly rural in nature with population densities as low as one person per square kilometer in some rural areas (Local Government New Zealand 2010). Although the trees in smaller rural towns still have the potential to provide a range of environmental, social, and economic benefits to these communities (Konijnendijk et al. 2005; Forest Research 2010) it could be argued that efforts to establish trees that can reach full maturity and subsequently deliver a higher level of environmental benefits are more crucial in heavily urbanized areas.

This is because of the challenges and limitations associated with establishing trees in the harsh urban environment and the increased potential for a range of environmental issues to exist in urbanized areas, such as problems with pollution and stormwater management.

Although 59\% of New Zealand's land is covered by a combination of native and exotic forests and vegetation (Ministry for the Environment 2002), this can create a false sense of security because much of this tree cover is located away from the main population centers, reducing the potential range of environmental, economic, and social benefits these trees can provide within New Zealand's urbanized areas. For example, trees growing hundreds of kilometers away will not contribute to improving the air quality in a highly urbanized area.

Although LAs have a key role in managing the trees in and around New Zealand's towns and cities, no major research covering LA tree management on a national scale has been completed. Previously, studies have focused on a specific local authority or subject of concern. For example, a study by Le Claire (2009) reviewed the tree management policies at one LA, and Serwylo (2010) focused on the changes in the amount of canopy in one of New Zealand's major cities.

\section{AIMS AND OBJECTIVES}

The aim of the research was to help ensure that current and future generations of New Zealanders can enjoy the benefits of well-managed tree populations in their towns and cities.

The study had three key objectives:

- Identify and analyze the resources available to LAs to manage New Zealand's urban forests.

- Assess the extent to which LAs were undertaking a planned, systematic, and integrated approach to the management of their urban forests.

- Make recommendations on how LAs nationally might improve standards of urban tree management. 


\section{METHODS}

A survey questionnaire was designed using the principles of Halmoborus and Holburn's (1995) model for social science research. This model is based on three key requirements: identifying what needs to be measured, selecting performance indicators, and then forming questions to measure the indicators chosen. This approach has been successfully used in the design of other major urban forestry surveys (e.g., Johnston and Rushton 1999; Johnston et al. 1999; Britt and Johnston 2008).

The majority of the questions in the questionnaire survey were in closed format, a style that is based on the respondent choosing from a number of alternatives provided by the researcher. A limited number of questions used scales to measure how respondents perceived their LA was performing in an aspect of tree management. The questionnaire was structured into distinct sections to assess the extent to which a planned, systematic, and integrated approach to urban tree management was being used (Johnston and Rushton 1998). A section was also included to assess a range of resource issues that could not be specifically grouped under these headings. This section asked respondents to provide a range of information about the financial and human resources available in each LA for tree management. Questions regarded the annual tree management budget, the number of staff involved in a tree management role, and details of any external funding the LA had received for its tree program. A number of questions about the gender, experience, professional background, and qualifications of the officer responsible for tree management in the LA were also included in this section. Although not a specific question in the survey, it was possible to calculate the amount of money spent per capita on tree management by each LA. This analysis was based on budget information provided by the LA and the resident population of the LA's district (Statistics NZ 2010).

The planned management section of the survey included questions about the type and extent of information each LA held about the urban forest. The questions focused on the extent LAs had surveyed their own trees in the last five years, the percentage of tree cover for their district and the percentage of the urban forest that was publicly and privately owned. This section of the survey concluded with a number of questions about the development of tree management strategies and plans.

The section of the survey covering systematic management was designed to assess the extent to which LAs had developed a systematic approach to a number of operations associated with the practical management of trees. Questions covered a range of areas; the amount of tree work that is planned and performed on demand, the use of computerized tree management systems, systematic tree inspections, post-planting maintenance, tree protection, utilization of debris and timber arising from tree operations, and tree selection criteria.

The integrated management section of the survey included a range of questions to assess the degree to which a holistic and coordinated approach for managing the trees in a LA's district had been developed within the LA and with public, private, and voluntary sector organizations.

A SWOT analysis was also incorporated into the questionnaire. This section asked respondents to rank the five most significant strengths, weaknesses, opportunities, and threats that they associated with their LA's tree program. This was included following the successful use of the technique by Britt and Johnston (2008). A robust and comprehensive coding structure was developed by Britt and Johnston (2008) and provided an ideal framework for coding the results of the SWOT analysis. The framework facilitated response coding, based on their content, into a series of categories under broader headings, such as planned, systematic, and integrated management.

To help reduce the potential for ambiguity associated with the physical separation of the researcher from the respondent in this type of survey, detailed guidance notes were designed to be used in conjunction with the questionnaire. The level of participation in self-administered questionnaires can be improved if the survey is given some form of advance publicity (Haralambos and Holburn 1995; Robson 2002). The New Zealand Arboricultural Association (NZAA) played a key role in helping to promote the research by publishing an article describing the aims, methods, and potential benefits of the research in the December issue of its members' publication, Tree Matters, and including an abridged version on its website. The questionnaire was pilot-tested to identify and resolve any problems with its design. The review group included a current tree officer at one of New Zealand's LAs and two experienced urban forestry researchers/practitioners based in New Zealand. In January 2011, survey 'packs' consisting of a survey questionnaire, a covering letter, and comprehensive guidance notes were distributed by surface mail to each of New Zealand's 73 LAs. A copy of the questionnaire, cover letter, and the guidance notes can be accessed on-line (Stobbart, 2011). Prepaid and addressed reply envelopes were included, acknowledging their potential to help increase response rates (Oppenheim 1992; Wilson and McClean 1996; Hayes 1997; Robson 2002).

Returned questionnaires were collated using spreadsheets and analyzed using a variety of statistical techniques (Wheater and Cook 2000). $\chi^{2}$ tests were used to determine if there was a significant association between the type of LA and a) the existence of a tree strategy, and b) the use of a computerized tree management system. $\chi^{2}$ values were corrected using Yates' Correction for Continuity Formula to compensate for the tendency of the chi-square test to overstate $\chi^{2}$ values in situations where only two variables are being tested. A t-test was used to compare the mean values of tree work being scheduled by City and District Councils. Values for p below 0.05 in these tests were considered significant.

Although it was possible that individual LAs could be identified from responses provided to the survey questionnaire, anonymity was ensured when the results were processed. Assurances of anonymity were included in both the survey questionnaire and the covering letter. This was considered important to encourage respondents to provide accurate information even though this could, potentially portray individuals or organizations unfavorably or if the aspect of tree management being considered had legal implications.

\section{RESULTS AND DISCUSSION}

Completed questionnaires were returned by 30 of the 73 LAs, giving a response rate of $41 \%$. The LAs that responded covered $46 \%$ of New Zealand's total resident population and represented 10 of New Zealand's 12 regions, thus the results reflect the range of physical environments and social conditions found throughout the country. The response rate is particularly pleasing in light of the disruption following the Christchurch earthquake in February 2011 and the number of LAs who were either directly affected or heavily involved in a disaster management role. 


\section{Financial and Human Resources}

Undoubtedly, the availability of resources, both financial and human, has a major bearing on the extent to which a planned, systematic, and integrated approach to urban forest management can be achieved. A theme running throughout the results was the scarcity of resources available to many LA tree programs. Respondents frequently regarded insufficient resources as being a significant threat to the efficient and effective delivery of their LA's tree program. The budget-setting process further challenged this situation, with many of the LAs indicating that tree management budgets were not being developed to reflect a planned level of service for the tree program, but were simply formulated on the basis of previous allocations. Considerable variations in the total annual LA tree management budgets were identified, which ranged from NZD $\$ 5,000$ to $\$ 1.2$ million. Three respondents stated that no specific budget for tree management had been established in their local authority.

Considerable differences were identified in the amount LAs were spending per capita. Values ranged from 57 cents to 15 dollars, with the majority of the LAs spending $\$ 7$ or less.

The mean value of the number of LA officers involved in a tree management role, expressed as full-time equivalents (FTEs) was 2.98. The number of FTEs ranged from 0.05 to $10 ; 35 \%$ of LAs employed 0.5 of a FTE or less. Although care is needed with the interpretation of these results, research in England (Britt and Johnston 2008) suggests that LAs with less than one FTE allocated to a tree management role were unlikely to be in a position to develop a planned, systematic, and integrated approach to urban tree management.

Income from external sources can play a significant role in helping develop and manage LA tree programs. Sixty-eight percent of LAs had not received any funding from external sources for tree-related activities or services in the current (2010-2011) or the previous financial year. A notable exception was a LA that received $\$ 300,000$ of external funding for its tree program in 2009-2010 and an additional \$150,000 in 2010-2011.

Thirty percent of the officers involved in a tree management role were female, which compares favorably to the $21 \%$ identified in a similar study in England (Britt and Johnston 2008). A significant feature of the results was the considerable length of time officers had spent in their current posts and in a tree management role. Fifty-two percent of officers had been in post for at least five years, with $17 \%$ having been in post for over 20 years. Thirty-eight percent of officers had between 10 and 15 years of experience in a tree management role and $23 \%$ had in excess of 20 years of experience. It is interesting to note that despite the officers having a tree management role, $74 \%$ of their job titles did not mention trees or tree management, suggesting that many of the officers have other responsibilities and were not involved in tree management in a full-time or dedicated role. There was considerable variation in the professional background and qualifications of the officers who were involved in a tree management role, with horticulture, parks and reserves, landscape, and environmental management all featured in the results. Only $30 \%$ of the LA officers stated they had a professional arboriculture qualification, and a limited number, $28 \%$, considered arboriculture to be their main professional background.

\section{Planned Management}

Understanding the nature and extent of the urban forest in a local authority's district is an essential first stage in developing a strategic and planned approach for managing this resource. One of the most significant results of the study was that many LAs lacked some basic information about the trees in their district. The majority were not able to accurately state the percentage of their district covered by trees and the extent these trees were publicly or privately owned. Many LAs only held limited information about their publicly owned trees, with considerable variation in the number and type of tree surveys carried out in the last five years.

It is widely accepted that the management of the urban forest should be directed by a long-term strategy or plan (Clark et al. 1997; Booth 2005; Schwab 2009; Van Wassenaer et al. 2012). Although many LAs reported that they had a relevant strategy in place, typically, these did not support the development of a comprehensive, planned and integrated approach to tree management. This was because the lack of basic information about the urban forest was undermining the planning process, making it impossible for many LAs to identify meaningful objectives and develop appropriate budgets, management plans, and performance measures. Based on the results of the $\chi^{2}$ test, City Councils were no more likely to develop a tree strategy than District Councils $\left(\chi^{2}=2.85\right.$, df1, $\left.P>0.05\right)$.

\section{Systematic Management}

A systematic approach is essential for efficiently and effectively undertaking many of the operations involved in the practical management of the trees in a LA's district (Kielbaso et al. 1988; Johnston and Rushton 1998). This is particularly important in towns and cities, because for trees to exist in the harsh urban environment there is an almost total reliance on humans to plant and subsequently manage the tree throughout its life (Clark et al. 1997).

The unpredictable nature of many of the factors that can affect trees growing in towns and cities, such as severe weather events, make it inevitable that an element of a LA's tree maintenance needs to be performed on demand. Despite this, it should be possible for LAs operating under normal circumstances, with appropriate levels of funding, to schedule the majority of their tree maintenance work in advance. The amount of tree work that LAs are able to schedule is a key indicator of the level of systematic management being achieved. Sixty-six percent of LAs indicated that the amount of tree work being scheduled in advance was below the $40 \%$ threshold originally suggested by Kielbaso et al. (1988), which is generally regarded as being indicative of a systematic approach. If the threshold was increased to $50 \%$ (which has been suggested given the advances in urban tree management), $79 \%$ of LAs would be below this level. The results of the t-test suggest a significant association exists between the type of council and the amount of tree work being scheduled in advance (t $=5.929, \mathrm{df}=21 P<0.01)$ with City Councils more likely to schedule greater amounts of tree work than District Councils.

The extent and frequency with which LAs inspect their trees directly affects their ability to develop a systematic approach to managing this public resource. As well as providing the data needed to develop and manage future work programs, inspections play a significant role in managing tree-related risks and in the event of litigation can be a fundamental part of a LA's defense. Considerable variation between the levels of inspections conducted 
by LAs was identified. Although differences between inspection regimes are inevitable, given the availability of resources and the nature and extent of a LA's tree population, considerable scope exists to make inspection regimes more risk-orientated. A significant feature of the results was that $60 \%$ of the LAs did not answer the question in the survey that related to the coverage and frequency of the LAs tree inspection program. A similar situation was encountered by Britt and Johnston (2008), and in this case, it was attributed to the possible legal ramifications associated with irregular and infrequent inspection regimes, despite the assurance of anonymity for LAs in the published results.

The ability to plan, store, and manage tree data is significantly improved by using a computerized tree management system. Although $40 \%$ of LAs indicated they were doing so, the results show considerable variability in the way and the extent these systems were being used. Traditional uses, such as maintaining inventories and dealing with enquiries, were well represented, but the use of systems to schedule tree work, capture tree data on site, and use GIS functions was relatively limited. Based on the results of the $\chi^{2}$ test, a computerized tree management system was more likely to be used in a city rather than by a District Council $\left(\chi^{2}=5.304\right.$, df $\left.1, P<0.05\right)$.

LA tree maintenance can generate substantial amounts of debris (brash) and timber. The methods and systems used to dispose of, use, or convert this brash and timber indicates if a systematic approach has been developed to manage an important and potentially expensive aspect of urban forestry. The majority of LAs were chipping most of their brash. Only $22 \%$ of LAs reported burning an element of their waste and $56 \%$ indicated that some of their brash was being sent to a landfill. Considerable scope exists to convert more of the wood arising from tree management operations for use as timber products, with LAs indicating less than $5 \%$ of their timber is currently being converted (a process that can generate additional income and help promote the green credentials of a LA's tree management activities).

While many LAs may not have the resources to systematically maintain the majority of their mature trees, reduced levels of post-planting maintenance can be an indicator that LAs are finding it particularly difficult to develop any significant level of systematic management. This can be caused by either chronic under-funding of the LA's tree program or simply the result of ambitious planting schemes that are not subsequently supported by sufficiently-high maintenance budgets. Although $33 \%$ of LAs were carrying out high levels of post-planting maintenance, the results do raise some concerns. Thirty-three percent of LAs were carrying out post-planting maintenance on less than half of their newly planted trees and $12 \%$ of LAs indicated that no post-planting maintenance was being carried out. Given the harsh nature of the urban environment, a lack of post-planting maintenance is likely to increase tree mortality rates and result in wasted planting and establishment costs.

The importance LAs attach to a range of tree selection criteria can provide useful insight into the concerns affecting LA tree management programs. It can also show the extent LAs are following a structured decision-making process when replacement or additional trees are being selected. The ratings allocated by respondents to a range of tree selection criteria highlighted considerable variability in the priorities being attached to the different factors. The ratings suggest that the ultimate size and longterm maintenance costs associated with a species were particu- larly significant factors in the decision-making process. Although these are logical considerations, the results raised an interesting point. The guidance notes issued with the questionnaire stressed that the ultimate size refers to difficulties beyond normal form and function, meaning that other social factors, for example, pressure from the public, has contributed to trees with a smaller ultimate size being selected for locations that could, in theory, accommodate a larger tree. This reflects a similar situation identified by Britt and Johnston (2008) in their research in England.

Another interesting feature of the results was the level of importance attached to matching the origin of tree species to the ethnicity of the community. Despite having considerable benefits in terms of promoting social integration and cohesion (Johnston and Shimada 2004), this was not considered a priority in some LAs but considered a very high priority in others. The reasons for this are unclear, but given the social diversity in many of New Zealand's communities, this is likely to be a social aspect of tree management that is underdeveloped in some LAs.

LAs also need to develop a systematic approach for managing activities and services in relation to the privately owned trees in their district. The results suggest there is scope for LAs to be more proactive in identifying and protecting trees that have significant amenity value. In addition, many LA officers felt that due to resource constraints their LA only had a limited ability to enforce tree protection policies and measures, particularly when the trees were located on or near development sites.

\section{Integrated Management}

Managing the trees in a local authority's district in a holistic and coordinated way can only be achieved if a wide range of public, private, and voluntary sector organizations work in partnership (Rowntree 1995; Grey 1996; Clark et al. 1997; Kuchelmeister 1998; Johnston and Rushton 1998; Konijnendijk et al. 2005; Schwab 2009). An integrated approach is also essential within the LA itself. This is particularly relevant as many policy areas, such as street design and park maintenance, are closely linked to the development of a vibrant urban forest. Many respondents regarded the lack of integrated management as being a significant weakness in the delivery of their LA's tree program. There is considerable scope to improve the level of coordination between LAs and other public sector organizations that are either involved in managing trees or whose activities can have a direct effect on the urban forest. A common theme identified in the results was the conflict between developing quality and extensive urban forests and the needs and dominance of traditional grey infrastructure, such as roads, sidewalks, and the provision of utilities. Respondents highlighted that trees were frequently being regarded as an expendable resource, with little or no consideration given to their value or retention when infrastructure schemes were being designed, constructed, and maintained.

Opportunities also exist to develop the degree to which LAs were managing the trees in their districts in partnership with organizations in the private and voluntary sector. The results suggest that LAs could be doing more to engage with businesses and major private and institutional landowners in their district. These groups can play a significant role by providing land and a range of other resources, such as donating money and time to help manage the urban forest. This is particularly relevant in the current social climate with many 
organizations keen to be involved in community-based environmental projects, promoting a green and public-spirited image.

The majority of LAs, $72 \%$, did not have a structured framework, such as a district-wide tree forum or committee, dedicated to helping plan and co-ordinate the activities of the various groups that had an interest in how the trees in their district were being managed. Although $18 \%$ of LAs indicated that a group had been established, the results suggest that in many cases there was scope to extend the type and number of groups represented.

Involving the community in managing the trees in a LA's district is essential in securing public support for the LA's tree program and influencing the way privately owned trees are managed. A balanced approached should be based on three key elements: education, consultation, and practical participation (Britt and Johnston 2008). An aspect of community involvement where the LAs were performing particularly well was the advance notification to residents of major tree management activities, which by their nature can often be contentious and highly emotive. Another encouraging feature of the results was the extent that LAs routinely consult with the community, using formal consultation frameworks, when new tree management policies and plans were being prepared. LAs were also involved in a wide range of community-based tree-related events and activities, such as tree planting schemes, distributing free or subsidized trees, and providing technical advice to residents. Although these types of activities are undoubtedly useful, other forms of involvement seem to be used only sparingly, such as school-related activities and public festivals. Although these results were encouraging, concerns raised in the SWOT analysis indicated that more needs to be done. LA officers highlighted a lack of political and public support as being a significant threat to the development and maintenance of an extensive and vibrant urban forest.

An area that can be particularly influential in shaping public opinion, perception, and attitude is the coverage given to tree-related matters by the local media. Clearly, the potential for negative coverage to undermine public support for the LA's tree program makes it important for LAs, as much as possible, to be proactive in presenting positive news about tree related events and activities to the media. Although it is encouraging that $64 \%$ of LAs stated that they either received frequent (on average once a fortnight) or moderate (on average once every two months) media coverage, there is considerable scope for LAs to improve their performance in this area with only $28 \%$ stating their media coverage was usually positive.

\section{RECOMMENDATIONS}

Local authorities face a number of challenges when trying to develop a planned, systematic and integrated approach to managing the trees in their district. These challenges can be categorized into four closely related areas (Britt and Johnston 2008; Schwab 2009):

- Creating stable and adequate funding

- Developing a vision that encapsulates the multitude of environmental, economic and social benefits that trees can provide

- Communicating the vision to the community and elected officials

- Developing a range of objectives, strategies, plans, and regulatory tools to deliver the vision

\section{Developing a National Framework}

The considerable variation identified in the LAs' performance in many aspects of tree management highlights the need to promote and develop a more consistent approach to LA tree management in New Zealand. Although LAs are ultimately responsible for identifying their tree management objectives and developing strategies and management plans to achieve them, consideration should be given to developing a national strategy and set of performance standards to support the development of LA tree management across New Zealand. Studies in the UK have shown the development of performance benchmarks in key aspects of tree management to be very useful in helping raise the standards of performance (Johnston and Ruston 1999; Britt and Johnston 2008). The establishment of a centrally-funded National Urban Forestry Unit made a significant contribution to the development of LA tree management in the UK by providing a comprehensive advisory service and publishing a wealth of practical information (Johnston 2000). Since this unit played a key role in promoting improved standards of LA tree management in the UK, a similar unit has the potential to be equally successful in New Zealand.

\section{Specialist Tree Management Skills}

The availability of specialist skills is fundamental to the continued development of LA tree management in New Zealand. It is essential that other associated and allied professions involved in the planning and management of urban areas and green space recognize that managing the trees in a LA's district requires specialist expertise. Although the practical aspects of tree management are quite rightly a key component of the arboriculture courses available in New Zealand, it is important that the specialist skills associated with developing a planned, systematic, and integrated approach to LA tree management are not neglected in the design and delivery of relevant courses/programs. LAs can help this process by prioritizing the need for specialist tree management skills throughout the recruitment and continuing professional development process. A range of specialist programs up to honors degree level is now available online and provides an excellent opportunity for LAs to support the continuing professional development of officers involved in a tree management role. It is recognized that in many of the smaller rural LAs, employing a specialist tree officer may not be a practical option. In these cases consideration should be given to establishing a 'shared post' jointly funded with other LAs in the region or contracting services from a larger, adjacent LA. In some regions with only a few major settlements, for example Northland, the establishment of a regional tree officer may prove to be the most cost-effective option.

\section{Canopy Goals}

Measuring the percentage of a district covered by trees is an essential prerequisite for setting strategic objectives, developing a comprehensive tree strategy, and monitoring changes in the extent and distribution of the urban forest. This information can, typically, be obtained from relatively inexpensive methods like aerial photography and may already be available within LAs or from other government agencies. LAs should work toward measuring levels of canopy cover and establishing specific canopy goals. It is important that canopy goals are set in consultation with the community and reflect the district's unique combination of geographical, climatic, social, and economic factors. Schwab 
(2009) highlights an approach successfully used in the United States that has considerable potential to be used in New Zealand. It defines canopy goals based on various zoning categories, such as suburban residential, urban residential, and central business districts. The effectiveness of this approach could be improved by working in partnership with Regional Councils given the considerable overlap between their areas of responsibility, such as stormwater management, and the key contribution trees can make to a range of environmental policies. This process could also be used to establish the proportion of the tree cover that is publicly and privately owned, a measure that can be particularly useful when policies and plans are being developed. For LAs operating in predominantly urban areas this process will involve measuring the canopy cover for the entire district, including the surrounding areas that influence the quality of urban life, such as watersheds. LAs operating in rural areas may find it more practical to focus on measuring and establishing canopy goals for the towns and settlements in their district. The use of specialist software like i-Tree should be considered. i-Tree was first developed in the U.S., and various i-Tree tools are available to download at no cost. The software provides a range of applications that enables communities of all sizes to inventory, manage, and monitor the canopy cover in their district (Schwab 2009). The software suite also includes analytical tools to enable some of the more tangible environmental benefits of urban tree populations, such as improvements in air quality, to be quantified.

\section{Comprehensive Tree Management Strategies}

Studies highlight the dilemma many LA tree officers operating in difficult conditions and within severe financial constraints face in the UK (Britt and Johnston 2008). Limited resources could be used to carry out more surveys and systematic inspections of the LA's trees, but in doing so even less money is available to carry out the maintenance work once it has been identified. Based on their research, Britt and Johnston (2008) stress that the only real solution to this dilemma is to develop a comprehensive tree management strategy that establishes clear priorities, targets, performance measures, and budgets. Although it is recognized that many of the LAs have some form of strategy in place, many of these can be improved. LAs should work toward developing comprehensive tree management strategies that cover the range of actions and interventions the LA will use to manage the publicly and privately owned trees in its district. The strategy should be based on agreed upon canopy goals and the results of surveys designed to establish the nature and extent of the urban forest in the LA's district. It is important that other professions involved in urban management recognize the vital role trees and tree management can play in achieving a range of environmental, economic, and social objectives. To help, the LA's tree management strategy should be clearly linked to and support the LA's District Plan and other relevant policy objectives and strategies. Periodic audits should also be considered to help ensure that each LA has a consistent and coherent approach to managing a range of policy areas. A community involvement strategy setting out the range of measures the LA will use to manage the trees in its district in partnership with the community and with organizations from the public, private, and voluntary sectors should be incorporated into the tree strategy. Studies (Johnston and Shimada 2004; Britt and Johnston 2008) highlight the importance of developing a range of activities that balance the three key elements of community involvement: education, consultation, and practical participation.

\section{Changing Perceptions}

A major threat to developing sustainable and effective LA tree management programs is the perception commonly held by some elected officials and members of the community that although trees offer some aesthetic benefits, they are largely an expendable commodity. The challenge facing LAs is to move to a position where trees are seen as a sound and even a preferred investment in the community's future (Britt and Johnston 2008; Schwab 2009). Public support for LA tree management is fundamental to its success. Although support can be in the form of resources, such as time and money, arguably the most significant form of support for a LA's tree program is the influence the public is able to exert on elected officials and their spending priorities, a process that Clark et al. (1997) aptly describe as "people who value trees, elect officials who value trees."

Although the development of a comprehensive tree management strategy is a fundamental part of the reorientation process, a number of techniques and tools, such as the use of i-Tree software, are available to enable LAs to quantify some of the more tangible benefits of the trees in their district. The information these techniques can provide can be a powerful tool in generating public support and securing funding for a LA's tree program (Schwab 2009; Rogers 2010; Hansford et al. 2011).

\section{Sources of Funding}

Studies in the U.S. (Schwab 2009) and the UK (Britt and Johnston 2008) highlight the potential for LAs to use innovative approaches to help stabilize funding levels for their tree programs and reduce the LA's dependency on public funding. Pursuing external sources of funding can also help when LA officers are trying to convince their LA to increase the level of funding for their tree program (Britt and Johnston 2008). External funding, such as grants, donations, and sponsorships are typically available from a range of organizations in the public, private, and voluntary sector. LAs should work toward incorporating external funding targets and plans into their tree management strategy. Identifying the various funding options is something that can usefully be done by a central body. This could be included in the remit of a national urban forestry unit, should one be established.

\section{CONCLUSION}

There are many encouraging aspects of the research that give cause for optimism. However, there are concerns that the strategic importance of trees in the urban environment is not always being recognized by the public and members of the local authority. Officers involved in LA tree management are frequently operating under difficult conditions and often within severe financial constraints, which is limiting their ability to develop a planned, systematic, and integrated approach. With a relatively small increase in funding, substantial progress could be achieved to facilitate the development of a truly planned and proactive approach to LA tree management.

In the long term, LA tree programs have a vital role to play in creating sustainable communities and contributing to the delivery of a range of environmental, economic, and social objectives and 
policies. With appropriate support and encouragement, LA tree programs can undoubtedly help improve the quality of life for many New Zealanders. However, there is the concern that unless action is taken to create the conditions and support that LA officers need, there is a real danger that the tree populations in New Zealand's towns and cities will steadily erode and devalue.

Acknowledgments. Many people have made this study possible. The local authority officers who took part in the survey have been instrumental to the research and their time and interest is truly appreciated. The New Zealand Arboricultural Association has played a key role in supporting and promoting the study. Rob Graham, Arboriculture Program Manager at the Waikato Institute of Technology, and Dr. Justin Morgenroth, Urban Forestry Researcher/Lecturer at the University of Canterbury have both provided valuable advice and support throughout the study.

\section{LITERATURE CITED}

Booth, J. 2005. Developing a sustainable community strategy for trees. Arboricultural Journal 29:5-18.

Britt, C., and M. Johnston. 2008. Trees in Towns II. A new survey of urban trees in England and their condition and management. Research for Amenity Trees No. 9. Department for Communities and Local Government.

Clark, J., N. Matheny, G. Cross, and V. Wake. 1997. A model of urban forestry sustainability. Journal of Arboriculture 23(1):17-31.

Forest Research. 2010. Benefits of green infrastructure. Report by Forest Research. Forest Research, Farnham.

Grey, G. 1996. The Urban Forest: Comprehensive Management. John Wiley and Sons.

Hansford, D., T. Jarratt, and K. Rogers. 2011. Torbay's Urban Forest. Assessing Urban Forest Effects and Values. A report on the findings from the UK i-Tree Eco pilot project. Treeconomics, Exeter.

Haralambos, M., and M. Holborn. 1995. Sociology: Themes and Perspectives. 4th ed. Collins Educational.

Hayes, B.E. 1997. Measuring Customer Satisfaction - Survey design, use and statistical analysis methods. Milwaukee, ASQ Quality Press.

Johnston, M. 2000. British urban forestry in transition: Developments between 1993-1998, part I. Arboricultural Journal 25:59-92.

Johnston, M., and B.S. Rushton. 1998. A Survey of urban forestry in Britain, part I: Aims and methods of research. Arboricultural Journal 22:129-146

Johnston, M., and B.S. Rushton. 1999. A Survey of Urban Forestry in Britain. University of Ulster, Ulster.

Johnston, M., K. Collins, and B. Rushton. 1999. A Survey of urban forestry in the republic of Ireland. In: K. Collins (Ed.). Proceedings of Ireland's Third National Conference on Urban Forestry. The Tree Council of Ireland, Dublin. pp. 72-99.

Johnston, M., and L. Shimada. 2004. Urban forestry in a multicultural society. Journal of Arboriculture 30(3):185-191.

Kielbaso, J.J., B.S. Beauchamp. K.F. Larison, and C.J. Randall. 1988. Trends in Urban Forest Management. Baseline Data Report, 20(1), International City Management Association, Washington, D.C.

Konijnendijk, C.C., K. Nilssoon, T.B. Randrup, and J. Schipperijn (Eds.). 2005. Urban Forests and Trees. Springer, Heildelberg.

Kuchelmeister, G. 1998. Urban Forestry in the Asia-Pacific Region: Status and prospects. APFSOS Working Paper No. 44. FAO, Forestry Policy and Planning Division and Regional Office for Asia and the Pacific, Rome/Bangkok.
Le Claire, A. 2009. A review of tree management policies at North Shore City Council, Auckland, New Zealand. Unpublished project completed for the Diploma in Arboriculture at the Waikato Institute of Technology, New Zealand.

Local Government New Zealand. 2010. Local Government in profile. Accessed 07/20/2010. <www.lgnz.co.nz>

Ministry for the Environment. 1991. Resource Management Act. New Zealand Government.

Ministry for the Environment. 2002. Land Cover Database (LCDB). Accessed 01/26/2011. <www.mfe.govt.nz/environmental-reporting/ about/tools-guidelines/classifications>

Oppenheim, A.N. 1992. Questionnaire Design: Interviewing and Attitude Measurement. London, Pinter Publishers.

Population Reference Bureau. 2010. World population data sheet. Accessed 01/24/2011. <www.prb.org./Datafinder/Geography/MultiCompare.aspx $>$

Robson, C. 2002. Real World Research: A Resource for Social Scientists and Practitioners-Researchers. Blackwell Publishing, Oxford.

Rogers, K. 2010. Who said money doesn't grow on trees? Tree News, Autumn/Winter 2010. pp. 24-25.

Rowntree, R.A. 1995. Towards ecosystem management. Shifts in the core and the context of urban forestry ecology. In: G.A. Bradley (Ed.). Urban Forest Landscapes: Integrating Multidisciplinary Perspectives. University of Washington Press, Seattle, Washington, U.S.

Schwab, J. (Ed.). 2009. Planning the Urban Forest: Ecology, Economy and Community Development. Planning and Advisory Report number 555. American Planning Association, Chicago, Illinois, U.S.

Serwylo, A. 2010. Changes in the tree cover in residential areas of Hamilton, New Zealand. Unpublished project completed for the Diploma in Arboriculture at the Waikato Institute of Technology, New Zealand.

Statistics New Zealand. 2010. New Zealand in profile: An overview of New Zealand's people, economy and environment. Statistics New Zealand, Wellington.

Stobbart, M. 2011. Managing trees in and around Aotearoa's towns and cities: A survey of urban forestry in New Zealand. Published dissertation. Accessed 01/30/2012. <www.myerscough. ac.uk/?page=subjects-arboriculture-matthew-stobbart-dissertation>

Van Wassenaer, P., A. Satel, W.A. Kenny, and M. Ursic. 2012. A framework for strategic urban forest management and monitoring. In: M Johnston and G. Percival (Eds.). Trees, People and the Built Environment. Forestry Commission Research Report. Forest Commission, Edinburgh.

Wheater, C.P., and P.A. Cook. 2000. Using Statistics to Understand the Environment. London, Routledge.

Wilson, N., and S. McClean. 1996. Questionnaire Design: A Practical Introduction. Ulster, University of Ulster.

\section{Matthew Stobbart}

Arborist

New Zealand

matthewstobbart@gmail.com

Mark Johnston, Ph.D.

Research Fellow

Arboriculture and Urban Forestry

Myerscough College

Bilsborrow, Preston, PR3 ORY, UK

mjohnston@myerscough.ac.uk 
Résumé. Les autorités locales en Nouvelle-Zélande sont responsables de la gestion de nombreux arbres publics qu'ils possèdent dans leur district et ont une obligation statutaire d'agir en tant que gardien environnemental envers les arbres qui ont une valeur culturelle ou sociale significative. Aucune recherche n'avait été complétée par le passé pour déterminer à l'échelle nationale l'efficience et l'efficacité de la gestion arboricole des autorités locales. Un questionnaire d'enquête a été mis au point afin d'évaluer l'ampleur de la gestion des arbres en terme de planification, de systématisation et d'intégration, et afin d'identifier les défis clés ainsi que les limites auxquels les autorités locales doivent faire face pour gérer la forêt urbaine.

Le questionnaire a été envoyé à chacune des 73 autorités locales de Nouvelle-Zélande. Trente questionnaires ont été retournés pour un taux de réponse de $41 \%$. On y a observé que plusieurs programmes locaux de gestion des arbres fonctionnaient sous des conditions difficiles et souvent sous de sévères contraintes financières. Le manque d'informations de base sur la forêt urbaine faisait en sorte qu'il s'avérait difficile pour plusieurs autorités locales de développer des stratégies et des budgets significatifs, ce qui se reflétait en de niveaux faibles d'entretien planifié. Les contraintes en ressources, les conflits de priorités et le manque de soutien public et politique ont tous été mis en évidence en tant que menaces significatives pour les programmes arboricoles.

Zussamenfassung. Die lokalen Behörden in Neuseeland sind für Pflege und Erhaltung der öffentlichen Bäume in ihrem Distrikt zuständig und haben die konstitutionelle Pflicht als Schützer für Bäume aufzutreten, die einen deutlichen gestalterischen oder kulturellen Wert haben. Es gibt bislang keine vorangegangene Studie, die die Effektivität und den Nutzen des behördlichen Baumschutzes auf nationaler Ebene umfassend untersucht hat. Es wurde ein Fragebogen entwickelt, um das Ausmaß der Baumerhaltung in Planung, Systematik und Integration zu untersuchen und um Schlüsselfragen und Begrenzungen zu identifizieren, mit welchen die lokalen Behörden bei der Arbeit konfrontiert werden.
Jeder der 73 lokalen Behörden in Neuseeland wurde ein Fragebogen geschickt. Dreißig Fragenbögen kamen zurück, das ergibt eine Rücklaufquote von $41 \%$. Viele lokale Baumerhaltungsprogramme laufen unter schwierigen Bedingungen und oft mit ernsten, finanziellen Beschränkungen. Ein Mangel an Basisinformationen über urbane Forstwirtschaft macht es für die lokalen Behörden schwierig, aussagekräftige Strategien und Budgets zu entwickeln. Dies wird durch den niedrigen Level an geplanter Baumerhaltung reflektiert. Resourcenbegrenzung, Konflikte zwischen den Prioritäten und ein Mangel an öffentlicher und politischer Unterstützung wurden hervorgehoben als signifikante Einschnitte für viele Baumerhaltungsprogramme.

Resumen. Las autoridades locales en Nueva Zelanda son responsables del manejo de muchos de los árboles públicos que tienen un significativo valor cultural en su distrito, y tienen la obligación de actuar como sus guardianes ambientales. No existe investigación a escala nacional de la eficiencia y efectividad de una autoridad local de manejo del árbol. Se diseñó un cuestionario para evaluar la extensión en que el manejo del árbol es planeado, sistemático e integrado, e identifica los desafíos y limitaciones de las autoridades de cara al manejo del bosque urbano. Se envió un cuestionario a cada uno de las autoridades de 73 localidades de Nueva Zelanda. Se regresaron treinta cuestionarios, dando una tasa de respuesta de $41 \%$. Se encontró que muchas autoridades locales de programas de manejo del árbol operan bajo condiciones difíciles y con frecuencia bajo severas limitaciones financieras. Un vacío de información acerca del bosque urbano hizo difícil a muchas autoridades desarrollar estrategias significativas y presupuestos y se reflejó en bajos niveles del mantenimiento planeado. La restricción de recursos, conflictos de prioridades y la falta de soporte público y político fueron todas resaltadas como amenazas significativas para muchos programas de los árboles. 